\title{
The Dialogue between Religion and Science in Today's World, in the View of Orthodox Spirituality ${ }^{1}$
}

\section{Gavril TRIFA}

Abstract: The Dialogue between Religion and Science in Today's World, in the View of Orthodox Spirituality. One of the core issues of today's world, the dialogue between science and religion has recently come to the attention of new fields of knowledge, which points to a change in some of the "classical" elements. Having a different history in the East and in the West, in Catholic and in Orthodox Christianity, the relation between faith and science has lived through some difficult centuries, marked by the attempt of some scientific domains to prove the universe's materialist ontology and thus the uselessness of religion. This paper aims to present an overview of the stages that marked the often radical separation of science from religion, by highlighting the mutations recorded during the past few decades not only in society but also in the lives of the young, as a result of the unprecedented development of technology. With technology failing to raise both communication and interpersonal communication to the anticipated level, recent research does not hesitate in emphasizing the unfavourable consequences brought about by the development of the means of communication, in terms of the human being's relation to oneself and to one's neighbours. The solutions we

\footnotetext{
${ }^{1}$ Priest, Reader GAVRIL TRIFA, PhD West University of Timişoara.
} 
have identified enable an update of the patristic model concerning the relation between religion and science, in the spirit of humility, the one that can bring the Light of life.

Keywords: modernity, technology, communion, communication, humility

\section{Preliminaries}

In a sentence that became classical a few decades ago in support of contemporary thinkers' preoccupations to identify a social model by which to avoid the disasters caused by the two world wars and their consequences, André Malraux declared that "The twenty-first century will have to be mystical or not at all.", The concern for global economic development has led not only to the emergence of an impressive number of technical means, often with amazing results in all areas, but also to the technicalization of life, which is visible particularly in respect to communication in general, and to interpersonal communication in particular.

The evolution of religiousness in recent years has shown that the image the past two millennia left on the religious experience is continually changing. Not only does morality not know higher standards, the human being's relationship to oneself does not improve, or there is no awareness of the human person's existential need to find oneself in communion with one's neighbours and the Supreme Person, but the global promotion of religious-moral models that are deeply antireligious engenders increasing violence, inequality and social confusion. The only field that actually had something to gain out of it is science, with some of its branches such as genetics feeling less and less obliged to obey certain classic ethical norms. On the one hand, genetics

2 It was André Frossard who in 1993 drew attention to the fact that the great French thinker used the word "mystical" and not "religious". Frossard added that "or not at all" was to be understood as a warning signal, urging people to look for thought models from the beginning of human existence on Earth, in order to avoid in the first century of the third Christian millennium people's preoccupation with technology, which was to be even greater than in the previous century. 
has speculated on some interreligious conflicts, while on the other hand, it began presenting itself to today's man as a viable alternative to or even as a new form of religiousness. The evolution of society's notable ideas is all the more interesting since science was the first to say "no" to religion, as a consequence of western Christianity's attempt to keep it under tight control.

\section{The Enlightenment and the beginning of science's separation from religion}

After the Middle Ages, a period also defined by the concern for the marriage of philosophy and religion, the new historical stages foresee the approach of different perspectives through people's newly awakened conscience supported by "confidence in the power of man's mind, of human reason and of the new instrument of taming the nature (natural science)"3. This heralds the Enlightenment, which aims to replace scholastic spirituality with scientific rationality. French Enlightenment in particular set out to impose the materiality of Christian perspective on God's creation of the world. Thus, in his work L'homme machine, Julien Offray de La Mettrie, "takes materialism to cynicism. God - he claimed - does not exist and the world will not become happy until atheism has become all powerful. The soul is nothing but an empty meaningless word unless we consider it part of the thinking body, the brain. The immortality of the soul is absurd; the soul, being part of the body, dies with it; once the body dies, everything has come to an end."4 The core ideas of French materialism, although countered to a certain extent by some philosophical perspectives based on the Bible and exemplarily supported by Descartes and Pascal, led to a decline in the reception of religious models and the increasing assertion of autonomous human reason in the public area.

3 Constantin Narly, Pedagogie generală (General pedagogy), Bucureşti, Editura Didactică şi Pedagogică, 1996, p. 175 (my translation).

${ }^{4}$ G.G. Antonescu, Istoria pedagogiei. Doctrine fundamentale ale pedagogiei moderne (History of pedagogy. Fundamental doctrines of modern pedagogy), apud Dorin Opriş, Dimensiuni creştine ale pedagogiei moderne (Christian dimensions of modern pedagogy), Bucureşti, Editura Didactică şi Pedagogică, 2012, p. 316. 
The positivist effervescence moments of the French Revolution represent a paradigmatic image of the radical change that occurred in the scientific realm. Turned into an ideology, science presented itself as an extremely generous offer for the entire civilization. The human person has become the measure for all things ${ }^{5}$, but in a subtler and more nuanced way: man does not only have the power to create many of the things he imagines, but he himself becomes the model. The fact that man can create becomes less and less important in the science-religion dialogue, being replaced by the danger that he may become god for himself. Behind this generous offer many things could lie hidden, including the human being's dissatisfaction with himself caused by the radical autonomization of intelligence and of human nature in general, with man becoming incapable of honestly and sincerely perceiving what lies beyond his own self.

The effects of this vain overlapping are incalculable, starting from the ecological crisis caused by the human being's disrespect for creation as a gift from God, all the way to secularization, globalization and their manifestation in a consumerist society which is permanently on the lookout for something, precisely because society feels the lack of permanently valid values, where the religious plays an important role as lived experience and not as mere theory. Nature itself has not escaped these dramatic changes. "Through science and technology man has achieved great power over external nature but remains powerless before the irrational forces he confronts within, thus becoming the slave of vices or of instincts derailed by sin. The price paid for technological advancement has contributed to the lessening of spiritual strength in the human being." It was long believed that God's presence in creation would be an obstacle to the progress of natural sciences. Yet today's great physicists, who have pierced with their mind the reality of the subatomic world, have reached the conclusion that behind the universe

5 Pico della Mirandola, Raţionamente sau 900 de teze. Despre demnitatea omului (Reasonings or 900 theses. On the dignity of man), Bucureşti, Editura Ştiinţifică, 1991, pp. 120-123.

${ }^{6}$ Dumitru Popescu, Omul fără rădăcini (Rootless man), Bucureşti, Editura Harisma, 1992 , p. 57. 
there is "a supreme order that regulates physical constants, initial conditions, the behaviour of atoms, and the life of stars"".

Unarguably united when it came to spreading the Gospels around the world, Christianity did not have, at a European level, the same attitude towards the development of science in the West and in the East, and the period of the Enlightenment fully highlighted the differences in understanding and dialogue between faith and science. The main accusation brought to Western Christianity, especially to Catholicism, is the lack of understanding of the different approaches which theology and science have, even if they both try to promote ideas and models focused on the human being and the world he lives in. The fact that religion and science suggest different perspectives from which the world can be understood was hard to accept in Galileo's time ${ }^{8}$, which resulted in a state of conflict, all the more so since both science and religion tried to dominate and control each other'.

Under the influence of a series of personalities in the fourth century, also known as Christianity's "golden age", Orthodox theology constantly provided a different perspective, first of all due to the fact that many Church Fathers in the previous centuries of Christianity had studied in some of the time's pagan schools, which helped them point out the manners to identify the Holy Ghost's work in the life and writings of non-Christian thinkers and which Dogmatic Theology now calls the natural moral law. Thus, in his "Address to Young Men", Saint Basil the Great recommended the close and selective reading of nonChristian texts. The Cappadocian father used allegory to show how non-Christian texts could be useful to Christians, inviting people to imitate bees which "do not visit all the flowers without discrimination, nor indeed do they seek to carry away entire those upon which they

7 Jean Guitton, Dumnezeu şi ştiinţa (God and Science), Bucureşti, Editura Harisma, 1992, p. 57.

${ }^{8}$ John F. Haught, Ştiinţă şi religie: de la conflict la dialog (Science and religion: from conflict to dialogue), Bucureşti, Editura Eonul Dogmatic, 2002, p. 26.

${ }_{9}$ Bertrand Russell, Religie şi ştiinţă (Religion and science), Bucureşti, Editura Herald, 2012, p. 22. 
light, but rather, having taken so much as is adapted to their needs, they let the rest go."10

Furthermore, the Eastern Church Fathers showed the real value of the scientific breakthroughs of their times, as well as the danger they posed for those who remained entrapped by them. The danger arose from the fascination and even the slavery brought about by a science that believed itself all-powerful. The invincibility of science was not and can never be proven, although it was not seldom that scientific truths claimed universal validity across time and space. The Eastern Fathers valorised the words "and God saw that it was good", repeated in the Book of Genesis, thus revealing the perspective of Reason that diversifies undivided into all things so that it can unite them all without confusion in itself. The rationality (in his image) of creatures gains access to conscience within the human person, only as long as he recognizes himself as the conscience of the universe, thus reflecting the aspiration of the entire creation towards God; this rationality is fully updated to the human being's ascent towards God.

\section{Communication and communion in the age of science and of technical means of communication}

Both in its natural and in its supernatural aspects, the spiritual foundation of the universe highlights the fact that the world represents the subject of the dialogue between the human person and God so that the former can advance both technologically and spiritually, and so that high technology, seen as one of modern science's forms of manifestation, can be placed in the service of life. Thus, we no longer have to place divine transcendence within immanence, in its pantheist meaning, in order to discover the basis for the reconciliation of science and faith. This basis actually exists and was inscribed by God in the internal constitution of all of creation into Christ, as Creative and

${ }^{10}$ Basil the Great, "Address to Young Men on the Right Use of Greek Literature", in Frederick Morgan Padelford, Essays on the Study and Use of Poetry by Plutarch and Basil the Great. Yale Studies in English 15 (1902) pp. 99-120. Available online: http://www.tertullian.org/fathers/basil_litterature01.htm [Accessed 27.01.2017]. 
Redemptive Logos, by the power of the Spirit of Ghost hovering over waters. The human being thus has the opportunity to know and get close to God both through supernatural and natural revelation, while science has the necessary premises for dialogue and reconciliation with religion for the common good. ${ }^{11}$

Considering current data, the human being seems to suffer not because of a lack of communication, but because of the interpersonal models underlying communication. Young people often say that the commonplace has become one of the criteria in conversation, that, for them, the dialogue of ideas has given way to truisms and conventionality, which are the result of the absence of genuine dialogue and of a decreasing practice of argumentation. In parallel to this "dialogical makeup", there is an overuse of technology as a main instrument in this act of pseudo-communication. The human being seems to have lost his ability to listen and to receive information ${ }^{12}$; he no longer knows how to think but only how to apply things. Technical means have now reached a stage in their development when they can turn against the human being. However, eastern theology believes that “technology appeared after man's fall into sin, as a means of his survival on earth. But when technology loses its connection to God and is used for domination and profit, it turns from technology in the service of life and transfiguration into technology leading to the disintegration of both man and nature, through atomic bombs, for instance." $" 13$

The human being's relationship to science is not conflict-prone in itself but it can turn into a conflict. The sense of self-preservation emerged when the human being thought he could be autonomous, outside the permanent dialogue with his Father and creator. "God did not create the world just to exist and function autonomously, but to have it in communion with Himself so that it can share into the eternal

${ }^{11}$ D. Popescu, Omul fără rădăcini (Rootless man)..., p. 74.

12 Virgiliu Gheorghe, Efectele televiziunii asupra minţii umane. Şi despre creşterea copiilor in lumea de azi (The effects of television on the human mind. And about raising children today), Bucureşti, Editura Institutul de Cercetări Psihosociale şi Bioetică, 2015, pp. 36-38.

${ }^{13}$ D. Popescu, Omul fără rădăcini (Rootless man)..., p. 85. 
life of the Holy Trinity. If the world had resulted from an autonomous evolution process, as it is often claimed, then it is difficult to understand why evolution has stopped with the appearance of the human being and has not continued with the emergence of superior beings." "In the age of technology, interpersonal communication thus invites us to meditate on the man-creator relationship. God created man in His image, as a free and responsible person, so that he may be a partner in dialogue and work together with God in order to achieve the Creator's immortality together with all of creation. So great is the human person's dignity that he may be said to be not only a "microcosm" but also a "microtheos", having the grand role of progressing, together with all of creation, towards the Creator's immortality ${ }^{15}$.

\section{The breakthroughs in the technical area of modern science, from means to purpose of the human existence}

Of course, science meets the human being's needs most of the time but, as a drawback, it spurs and multiplies them ad infinitum. Nowadays, human beings are always looking for the spectacular, where value seems to become the novelty in itself. The rush in meeting materialistic needs and the almost discretionary power of advertising and consumerism ${ }^{16}$, which artificially multiply such needs, constantly push man's heart away from God and spiritual values ${ }^{17}$. The science emerged from autonomous reason, which shuns God, resembles the tree of the knowledge of good and evil in the Garden of Eden. On the one hand, it seems good and serves many of man's vital interests. On the other hand, it turns against the human being with a terrifying power of

${ }^{14}$ Ibidem, p. 65.

15 According to the exemplary model proposed by Saint Maximus the Confessor and later developed by Saint Simeon the New Theologian.

16 Alexandru Taşnadi, Econoteologia (Econotheology), vol. 1, Satu-Mare, Editura Eco Print, 2016, pp. 12-18.

${ }^{17}$ Dumitru Popescu, Ortodoxie şi contemporaneitate (Orthodoxy and contemporaneity), Bucureşti, Editura Diogene, 1993, p. 161. 
destruction $^{18}$. The autonomous technical standpoint tends to transform into purpose in itself and cause man to forget about the meaning of life and his existence. Technology is and can be nothing but an instrument, not a purpose. There are no technical purposes of life; there are only technical means. Purposes belong to the realm of spirit. The human person will never be able to achieve supremacy of spirit in order to overcome the difference between scientific and spiritual progress if he continues to stay bent on himself, trapped in the immanence of a world that wants to be autonomous; that is only possible in unity with the very first and inexhaustible source of life, light and love, which is God. When man gives up on God, thinking he can develop on his own, he can no longer overcome the passionate drives in his being and considers them normal and natural, thus becoming their slave. Instead of aiming to be like God, trying to be the master of his own being, the human person begins to be dominated by irrational drives, which he cannot control $^{19}$.

Science taken to the extreme and the sophistication of means have resulted in a proud superiority of autonomous human reason. The traditional and the modern world are now divided with regard to technology, but man's life does not take place on a more stable ground, there is no decrease whatsoever in the uncertainty of one's own destiny. Whereas the Greeks called "techne" the science of crafting, of craftsmen who made and used instruments, people in Antiquity and in the Middle Ages believed that technology had a mystical aura and that it provided a direct connection between the human being and nature. Once with modernity however, we witness the invention and expansion of instruments on a wide scale, with instruments becoming more and more automatized. The steam-machine was the first model, making possible the expansion of the Industrial Revolution in Britain. Yet far from an industrial revolution, the technical machine represented a genuine cultural mutation, leading to a cultural revolution.

18 D. Popescu, Ortodoxie şi contemporaneitate (Orthodoxy and contemporaneity), p. 161.

${ }^{19}$ Ibidem, p. 171. 


\section{Contemporary society: between the exponential development of science and the need for a dialogue with religion}

Despite all the amazing discoveries today, scientific thinking is indebted to a fragmentary methodology, which starts from complex reality and ends up at the elementary entity. "If we are to appreciate correctly the type of ontology subjacent to contemporary science, we have to admit that science actually touches reality but only knows it by fragmenting it and reducing it to a hierarchy united at various levels... Any philosophy of nature or any kind of theology that wants to take into account the breakthroughs of technology must not forget science's specific mode of understanding reality" ${ }^{20}$. If the science of a previous age can be considered ethically neutral, today the attitude of science towards ethics may be regarded as doubtful. Why? Because contemporary science relies on highly technical means and state-of-theart technologies. We cannot think of high level science without an adequate material infrastructure. For this, however, enormous financial resources are needed. Although these resources are given for a so-called scientific advancement, it is hard to believe that there is no purpose within the financing system.

Even through its most prominent representatives, science shows that it does not share into the fullness of the revealed Truth. Focusing on the created reality, science constantly overcomes its own limits just as it becomes aware of them. When science gives up its arrogant safety (which often defines positivism), the certainties posited and based exclusively on analytical demonstrations ${ }^{21}$, it can guess at (and even confess to) the existence of mystery. In such circumstances, science no longer claims to explain and understand everything, but it admits that, above its rigorous laws and formulas, there is something higher and deeper that eludes any demonstration. Admitting to its own limits, science is thus closer to Truth than in any exhaustive demonstration

${ }^{20}$ Dominique Lambert, Sciences et théologie: les figures d'un dialogue, Bruxelles, Éditions Lessius, 1999, p. 25.

${ }^{21}$ Răzvan Andrei Ionescu; Adrian Lemeni, Dicţionar de Teologie Ortodoxă şi ştiinţă (Dictionary of Orthodox Theology and Science), Iaşi, Editura Doxologia, 2016, pp. 2223. 
(however coherent and rigorous it may be), and it is precisely because of that that science and religion can meet in such a context ${ }^{22}$. Nevertheless, in this situation too, science can hardly work out the reality of the revealed Truth. If theology is a testimony of direct experience with the Truth-Christ, a manifestation of this Truth, science (in its highest forms) can testify to the assumption of mystery, to the experience of a religious thrill, to the joy of wonder before a world that cannot be exclusively conquered by reasoning. To eliminate ambiguity, we must become aware that scientists' assumption and acknowledgement of mystery does not necessarily mean that they actually assume the full Revelation.

\section{The Orthodox model: the dialogue between religion and science in the spirit of humility}

The honest dialogue between religion and science can actually occur only when it is understood as mutually advantageous. Sometimes science's need for dialogue with religion stems from a certain reciprocal dependency, as Albert Einstein suggests: "even though the realms of religion and science in themselves are clearly marked off from each other, nevertheless there exist between the two strong reciprocal relationships and dependencies. Though religion may be that which determines the goal, it has, nevertheless, learned from science, in the broadest sense, what means will contribute to the attainment of the goals it has set up. But science can only be created by those who are thoroughly imbued with the aspiration toward truth and understanding. This source of feeling, however, springs from the sphere of religion. [...] I cannot conceive of a genuine scientist without that profound faith. The situation may be expressed by an image: science without religion is lame, religion without science is blind." 23 It is now

22 To acknowledge the limits of contemporary science we might stop at the writings of a contemporary scholar, John Horgan, La science progresse, les mystères aussi, Le Courrier, nr. 5, 2001, p. 28.

23 Albert Einstein, "Religion and Science", in The New York Times Magazine, 9 November 1930, pp. 1-4.Available online: http://www.sacred texts.com/aor/einstein/einsci.htm [Accessed 27.01.2017]. 
mandatory to become aware of the manner in which patristic methodology, without opposing scientific methodology in principle, does not align itself with it but places itself above it, as a result if divine revelation. This is superknowledge, a view of the world's realities resulted from a spiritual understanding of the mysteries of the origin and purpose of the cosmos, which lies beyond discursive and analytical logic based on disparate pieces of information interconnected exclusively by non-spiritualized reason.

When the solutions suggested by the Holy Fathers and by science are divergent, choosing one option can only be an act of faith. It is hard to believe that we can understand the sophisticated theories presented by contemporary science concerning the origin and purpose of the world, even if some of them try to come close to the Biblical text interpreted literally ${ }^{24}$. To accept them is to rely on trust (which comes almost instinctively nowadays because of the mentality nowadays), the trust we place in science. The discrepancy, when it appears, is not necessarily due to the ideas and the dynamics of science, but rather to an assumed selfishness of autonomous intelligence to see nothing else but its own accomplishments. This alienation of science is a consequence of the superficial knowledge in which humankind has chosen to ground its relationship to itself.

At the same time, seeing arts and technology as the only acceptable methods to decode the world, the human being understands with increasing difficulty that any piece of knowledge is the result of the applied method and that science, just like technology, only gives him what he wants to know. The end of the crisis caused by technology and by convenience, as shown in art and felt in daily life, is not possible without a remodelling of the premises and intentions of contemporary science so that it becomes again interested in its own destiny, consistent with the intrinsic order of the world. This remodelling requires the transfiguration of the human mind towards the acknowledgement of creation from the perspective of its rational foundation in an attempt of theocentric reorientation. The human being has stopped looking for

${ }^{24}$ J.F. Haught, Ştiinţă şi religie: de la conflict la dialog (Science and religion: from conflict to dialogue)..., pp. 26-27. 
God in creation and has thus become enslaved to the illusion of autonomy, simultaneously threatening the very basis of life on earth. Only by returning to God will he find himself again and will he discover his genuine relationship with the world. Such an approach seems now more possible than ever, given that science and philosophy have already begun to demolish the myth of the paradise lived in the now - built by man through his own abilities - and to pave the way towards an accurate evaluation of civilization.

In its turn, the tradition of the Church suggests the saints as a model of a natural relationship between the human being and nature. The saints' experience does not consist only of gentleness towards all creatures until the moment of passing but has a purpose that transcends time and the current state of affairs. The human being's solidarity with all of creation, his sympathy for "inferior" kingdoms, without implying his devaluation, permeates their common call - the eternal union with God. Even if this divine communion is done differently according to each creature's reason or measure, its accomplishment determines the fullness of the relationship between the human being and creation. Relations between man and the world are not limited to the latter providing a living environment for the former, or, from a more complex perspective, some information about God, about itself and the human being; neither are such relations exhausted in the human being's condescending worrying about the world.

The two aspects (the world as space and the human being as master) of understanding the relations between the human being and creation emerge as the consequence of an omission in the Biblical text misunderstood by modern theology, namely the absence of a clear statement about the rationality of the prehuman creature in the Biblical essay regarding creation. As Moses had not said - since every creature is rationally constructed and bears an imprint of Logos, an omission motivated perhaps by the effort to avoid any pantheist suggestion - that images of the Word exist in all things, that all things are at different levels or, more precisely, at various degrees of rational awareness, in the image of God, as is the human being, it was inferred that the human being is superior to the rest of creation (based on the claim that he is the only one in God's image), while the world was understood as an 
insignificant reality, devoid of spiritual meaning and of a call in its union with God (even if this union was done through the human being). Another reason for this omission may be the need to assert the convergence of all of the visible and invisible creation in the human being.

The paradigm and the starting point of this ascent is Christ, who, revealing himself in everything as the Logos of creation, turns all things alive, reopening them to the rivers of divine energies, delivering them all from the delusional and superficial perspective of autonomy, i.e. showing them in their authentic light, raising them all with himself to the right hand of the Father ${ }^{25}$. The liturgy of the Ascension, following those of the embodiment and descent to the river Jordan, is the doxological expression of a theology embedded in cosmology, since Christ does not resume in himself all of humankind but all of creation. Ascension is not a mere private event in our Saviour's life; it is the celebration of restoring the choir of creation, as angels, people and all creatures praise the fulfilment of the age-long mystery - the deification of the world by Jesus Christ and the Church.

"Behold, the kingdom of God is within you" (Luke 17:21), says the Lord, but when we pray, we say "thy kingdom come!" The victory is won, but we are waiting for it to happen. The kingdom of God has shown itself in the midst of people, as a sort of dough of renewal, but it has to be updated within all of creation. This is where the human being intervenes; without his free support, Christ remains a simple moment in history, a fruitless attempt. In Christ, the human being is necessary to perfect creation, just as rain helps the earth bear fruit. Restored to his dignity as priest of creation, of intermediary between creation and God, the human being can and must raise the universe with him towards God, a process which begins with man's acknowledging his created

${ }^{25}$ Saint Athanasius of Alexandria, Tratat despre intruparea Cuvântului (Treaty on the embodiment of the Word), apud Saint Maximus the Confessor, Ambigua. Tâlcuiri ale unor locuri cu multe şi adânci înţelesuri din Sfinţii Dionisie Areopagitul şi Grigorie Teologul (Ambigua. Interpretations of some texts with many and deep meanings from Saints Dionysius the Areopagite and Gregory the Theologian), in the P.S.B. collection, vol. 80, Bucureşti, Editura Institutului Biblic şi de Misiune al Bisericii Ortodoxe Române, 1983, p. 328. 
condition and his place within creation. The Romanian phrase "the man sanctifies the place" sums up the patristic message: the human being ascends through the entire cosmos, using as steps other creatures' reason by contemplation, just as the entire cosmos ascends through the human being; man's parts are the cosmos, the components of the world. The cosmos is united in the human being; it is reshaped in man and by man through epektasis, through the slopes he climbs towards God through creation ${ }^{26}$. The human being cannot ascend otherwise than through creatures. Creation, as cosmic revelation, would be useless if the human being ignored it in his relation to God.

The Holy Fathers' message, rediscovered by theological thought in the twentieth century ${ }^{27}$, similar to the cosmic spirituality of eastern theology, goes beyond any anthropocentric individualism in salvation, beyond any separation between the human being and creation. At the same time, we can say that the Romanians have experienced this relationship more concretely, as brethren to the forest and all creatures. Only such a perspective, as foundation and motivation, can generate long-lasting success in ecological action. Today's people have reached the moment when they must choose between Adam and Christ - writes Father Stăniloae ${ }^{28}$-, as the "two alternate ways in which the human person relates to nature: the enslavement of his spirit by the sweet fruit of the sensible part of nature, or the mastery of nature through the spirit - not, of course, without the effort attendant upon renouncing the sweets of nature, nor without the effort implied in the sufferings of the cross. Only thus does

${ }^{26}$ Cf. Saint Maximus the Confessor, Ambigua. Tâlcuiri ale unor locuri cu multe şi adânci înţelesuri din Sfinţii Dionisie Areopagitul şi Grigorie Teologul (Ambigua. Interpretations of some texts with many and deep meanings from Saints Dionysius the Areopagite and Gregory the Theologian), in the P.S.B. collection, vol. 80, Bucureşti, Editura Institutului Biblic şi de Misiune al Bisericii Ortodoxe Române, 1983, pp. 260261.

${ }^{27}$ Răzvan Andrei Ionescu, Teologie ortodoxă şi ştiinţă: conflict, indiferenţă, integrare sau dialog? Care să fie atitudinea noastră faţă de ştiinţă? (Orthodox theology and science: conflict, indifference, integration or dialogue? What should our position towards science be?), Iaşi, Editura Doxologia, 2015, p. 37.

${ }^{28}$ Dumitru Stăniloae, Orthodox Dogmatic Theology, vol. II, The World: Creation and Deification, Brookline, Massachussetts, Holy Cross Orthodox Press, 2000, p. 46. 
the human spirit overcome the sensible part of nature and transfigure it until nature attains to the resurrection" (as a new way of being).

\section{Conclusions}

The dialogue between religion and science has become today as necessary as it is difficult. On the one hand, the confusion that envelops the human being connected by the media to the tragic aspects of life overlaps with his temptation to find refuge in materialistic values offered via increasingly sophisticated marketing techniques. On the other hand, science is less concerned with distinguishing itself radically from religion, justifying itself through its own breakthroughs, as a consequence of its failure to demonstrate the material ontology of the universe. Moreover, the unprecedented development of technical means has not led, contrary to what was expected, to the increase of interpersonal communion, but rather to greater solitude. This is also undoubtedly the result of the change in social relations, the technicalization of an increasingly larger number of jobs, the wide use of computers and phones in people's professional and personal lives. What was once considered a great opportunity can today become an obstacle to the human being's communion with himself.

For science, the dialogue with religion has become a priority, especially after the great disasters of the twentieth century and after the wrong use of atomic energy, which almost a hundred years ago was considered humankind's great chance at development. It is also a priority in terms of identifying solutions for the global ecological crisis, solutions which the entire humankind can apply. The Orthodox perspective on the dialogue between religion and science starts from the models offered by the Eastern Church Fathers, who did not see a danger in the development and valorisation of science as long as the human being does not set his heart on them, as long as he does not turn them into idols. Eastern theology considers that science gives us one structure at the most from all the things and ideas God used in creation, whereas revelation shows us the way towards a direct and life-giving communion with Him. In this dialogue, the way of humility is the way of harmony - this, however, on condition that we accept the reality 
stated by numerous scientists over the past few centuries, namely that each of the two domains has access, and consequently operates, in different percentages of course, with rational and suprarational data.

\section{References:}

1. Saint Basil the Great, "Address to Young Men on the Right Use of Greek Literature", in Frederick Morgan Padelford, Essays on the Study and Use of Poetry by Plutarch and Basil the Great. Yale Studies in English 15 (1902) pp. 99-120. Available online: http://www.tertullian.org/fathers/basil_litterature01.htm [Accessed 27.01.2017].

2. Della Mirandola, Pico, Raţionamente sau 900 de teze. Despre demnitatea omului (Reasonings or 900 theses. On the dignity of man), Bucureşti, Editura Ştiinţifică, 1991.

3. Einstein, Albert "Religion and Science", in The New York Times Magazine, 9 November 1930, pp. 1-4. Available online: http://www.sacred-texts.com/aor/einstein/einsci.htm

[Accessed 27.01.2017].

4. Gheorghe, Virgiliu, Efectele televiziunii asupra minţii umane. Şi despre creşterea copiilor in lumea de azi (The effects of television on the human mind. And about raising children today), Bucureşti, Editura Institutul de Cercetări Psihosociale şi Bioetică, 2015.

5. Guitton, Jean, Dumnezeu şi ştiinţa (God and science), Bucureşti, Editura Harisma, 1992.

6. Haught, John F., Ştiinţă şi religie: de la conflict la dialog (Science and religion: from conflict to dialogue), Bucureşti, Editura Eonul Dogmatic, 2002.

7. Horgan, John, La science progresse, les mystères aussi, Le Courrier, nr. 5, 2001.

8. Ionescu, Răzvan Andrei, Teologie ortodoxă şi ştiinţă: conflict, indiferenţă, integrare sau dialog? Care să fie atitudinea noastră faţă de ştiinţă? (Orthodox theology and science: conflict, indifference, integration or dialogue? What should our position towards science be?), Iaşi, Editura Doxologia, 2015. 
9. Ionescu, Răzvan Andrei; Lemeni, Adrian, Dicţionar de Teologie Ortodoxă şi ştiinţă, Iaşi, Editura Doxologia, 2016.

10. Lambert, Dominique, Sciences et théologie: les figures d'un dialogue, Bruxelles, Éditions Lessius, 1999.

11. Saint Maximus the Confessor, Ambigua. Tâlcuiri ale unor locuri cu multe şi adânci înţelesuri din Sfinţii Dionisie Areopagitul şi Grigorie Teologul (Ambigua. Interpretations of some texts with many and deep meanings from Saints Dionysius the Areopagite and Gregory the Theologian), in the P.S.B. collection, vol. 80, Bucureşti, Editura Institutului Biblic şi de Misiune al Bisericii Ortodoxe Române, 1983.

12. Narly, Constantin, Pedagogie generală (General pedagogy), Bucureşti, Editura Didactică şi Pedagogică, 1996.

13. Opriş, Dorin, Dimensiuni creştine ale pedagogiei moderne (Christian dimensions of modern pedagogy), Bucureşti, Editura Didactică şi Pedagogică, 2012.

14. Popescu, Dumitru, Omul fără rădăcini (Rootless man), Bucureşti, Editura Nemira, 2001.

15. Popescu, Dumitru, Ortodoxie şi contemporaneitate (Orthodoxy and contemporaneity), Bucureşti, Editura Diogene, 1993.

16. Russell, Bertrand, Religie şi ştiinţă (Religion and science), Bucureşti, Editura Herald, 2012.

17. Stăniloae, Dumitru, Orthodox Dogmatic Theology, vol. II: The World: Creation and Deification, Brookline, Massachusetts, Holy Cross Orthodox Press, 2000.

18. Taşnadi, Alexandru, Econoteologia (Econotechology), vol. 1, Satu Mare, Editura Eco Print, 2016. 